\title{
Some Early Iowa Agricultural Organizations
}

\author{
By Myrtle BeinhaueR*
}

Almost as soon as Iowa Territory was created, the attention of the landowner was turned to the problems of improving his status. In fact, the first General Assembly in 1838 passed a law providing for the organization of county agricultural societies. Since this opportunity was not immediately taken advantage of, subsequent legislative encouragement for the forming of similar organizations was soon enacted. In 1842 the formation of a Territorial Agricultural Society was authorized and a year later a statute permitting the organization of local societies was again passed. From that time on, such societies were organized in rapid succession.

Before the turn of the century there were few farm organizations other than the county and state agricultural societies, but since that time their number has been legion. A brief study shows that all farm organizations in Iowa may be divided into two general groups: those organized for the purpose of increasing production and promoting internal improvement and those organized to improve the economic welfare of the farmer by assisting him in marketing his produce.

Some of the early organizations are still active and are still performing valuable services for the farmers of Iowa. Others appeared, operated for a while, and succumbed to newer organizations or, having served their purpose ceased functioning. The purpose of this study is to trace the history of four organizations which are no longer active but which made valuable contribution to the agricultural development in Iowa.

Iowa Improved Stock Breeders' Association

Of these four organizations, the Iowa Improved Stock Breeders' Association was the oldest, having been founded by a small group of farmers in Cedar Rapids in June 1875. According to Judge Z. C. Luse, president of the

\footnotetext{
- Assistant Professor of Economics, Western Michigan University.
} 
society, in an address to the annual convention in 1881 , these stockmen sought to protect themselves against swindlers, to disseminate knowledge on stock raising, and to ascertain the best methods of producing milk and of feeding livestock. ${ }^{1}$

In this same address, Judge Luse explained the two types of swindling to which the stock breeders of that day were subjected. The first of these was the distribution of barren animals, shipped from other states, chiefly Kentucky, as purebreds. The other was the peddling of cull calves. These animals were shipped predominantly from Wisconsin and Illinois and sold as purebreds to the unsuspecting farmers at large, well-advertised sales. ${ }^{2}$

In 1875 the organization was called the Iowa Stock Breeders' Association, but in 1880 it became the Iowa Improved Stock Breeders' Association. This change permitted the society to expand its membership, because the new name implied that anyone interested in "improving" livestock was eligible to membership, while the first name gave the impression that only breeders of livestock could participate in the Association's activities. $^{3}$

The Iowa Improved Stock Breeders' Association became popular in the state. By 1880 it boasted fifty members, three of whom were honorary. ${ }^{4}$ Its meetings were open to all and, as a result, more than two hundred persons attended the sixth annual convention in $1880 . .^{5}$

The immediate concern of the society, protection against unscrupulous stock dealers, was achieved in six years. The organization's annual report of 1881 tells us that at that time there was not a "calf-peddler"

1 Iowa State Agricultural Society, Annual Report, 1881 (Des Moines: State Printer, 1882), pp. 14-15.

2Ibid., 1881, p. 15.

3 Ibid., 1880, p. 105.

4 The membership fee of the organization was two dollars with one dollar annual dues.

5 Iowa State Agricultural Society, Annual Report, 1880 (Des Moines: State Printer, 1881), p. 8. 
in the state. ${ }^{6}$ However, the Association continued its work of disseminating knowledge on the care of livestock. In doing this, the members discussed such subjects as "Grasses for Iowa," "New Conditions in Hog Raising," "Sheep," "Pastures," and "Milch Cows" at their regular meetings. But they did not confine themselves to the study of livestock and before long they showed concern for improving the social and educational aspects of farm life. ${ }^{7}$

During the early years of its existence, the Iowa Improved Stock Breeders' Association played an important role in the state and its work was deemed valuable enough for the Iowa state legislature to pass "An Act to Provide for the Publication of the Annual Proceedings of the Iowa Improved Stock Breeders' Association." This act authorized the publication of not more than five thousand copies of the report under the supervision of the Association as the reports of the State Horticultural and State Agricultural Societies were then published. ${ }^{8}$

After a time interest in the organization lagged. Although the activities of the society helped the farmer increase his production, he apparently did not consider these advantages great enough to warrant his continued support of the Association. The leaders were not especially responsible for this sentiment. The income of the organization was derived solely from membership fees. Without state aid or other sources of financial support extensive experiments could not be conducted nor could the most competent authorities on the various problems of stock raisers be obtained. Consequently, many needs of the farmer were not met. As a result, the membership of the society and attendance at its annual conventions gradually decreased. After thirtyone years of service the Association died a natural death. It was included among the "Farm Organizations"

${ }^{6}$ Ibid., 1881, p. 2.

7 Ibid., 1901, p. 158.

${ }^{8}$ Laws of Iowa, 1884, Chapter 134. 
in 1906, but since that time has not been mentioned in the Iowa Year Book of Agriculture.

\section{Iowa Swine Breeders' Association}

While the immediate reason for the creation of the Iowa Swine Breeders' Association may seem of minor importance, it was one of the state's early agricultural societies and for over thirty years it helped promote the welfare of the Iowa farmer. The inception of the organization resulted from the dissatisfaction of the swine breeders with accommodations accorded them at the State Fair. ${ }^{\theta}$ The swine breeders desired facilities as good as those of other stock raisers, so they met in Judge Nourse's tent September 4,1882, to discuss the best methods of obtaining them. This meeting resulted in the formation of the Iowa Swine Breeders' Association with B. R. Vale as president. ${ }^{10}$

After organizing, the members had difficulty in obtaining a hearing before the Board of Directors of the Iowa State Fair. Finally they were permitted to plead their cause and from that time on the swine breeders felt their needs at the Fair were more adequately met. ${ }^{11}$ By 1907 the legislature appropriated $\$ 75,000$ for the erection of better swine quarters at the fairgrounds. ${ }^{12}$ This measure, introduced by John McAllister of Linn county, ${ }^{13}$ was the first asking for state financial support for this group.

Besides improving accommodations at the State Fair, the members discussed problems confronting them in their daily life. At their annual meetings, the best methods of feeding, breeding, and caring for their swine were considered and thus valuable information was given to the interested farmers.

9 Iowa State Department of Agriculture, Iowa Year Book of Agriculture, 1901 (Des Moines: State Printer, 1902), p. 171.

10 The membership fee of this society was one dollar. with annual dues of twenty-five cents.

11 Iowa State Department of Agriculture, Iowa Year Book of Agriculture, 1901 (Des Moines: State Printer, 1902), p. 171.

12 Laws of Iowa, 1907, Chapter 204.

13 Iowa State Department of Agriculture, Iowa Year Book of Agriculture, 1907 (Des Moines: State Printer, 1908), p. 228. 
For a time the organization grew and by 1904 over one hundred attended the annual meeting of the Association, but soon thereafter its decline began. Its annual report of 1909, written for the Agricultural Year Book, stated that the number present was unusually small. ${ }^{14}$ However, the organization continued until 1916, which is the last time it received mention among the "Farm Organizations" in the Iowa Year Book of Agriculture. Nevertheless, it had accomplished its original purpose by obtaining a fine pavilion and show ring for the swine breeders and exhibitors at the Iowa State Fair. In addition it served to disseminate much information on the improvement of swine production and thus helped Iowa become one of the leading hog-raising states of the nation.

Iowa Seed Corn Breeders' Association

The shortest lived of this group of organizations was the Iowa Seed Corn Breeders' Association. Very early in 1901 N. J. Harris, A. L. Plummer, John E. Brown, Charles Page, D. B. Patterson, and Fred Hethershaw issued a call for a meeting of the corn growers of the state. ${ }^{15}$ In response to this call, a small group of men met at Des Moines in February of that year and organized this Association. ${ }^{16}$

In giving their reason for organizing, these men stated that, although no crop in Iowa could compare with that of corn, none was as badly neglected. They also said that corn was very susceptible to improvement and that they intended to improve it. ${ }^{17}$ This intent is borne out by the Association's constitution, which stated its purpose as being:

... to organize the originators, introducers, and the growers of improved varieties of seed corn for their mutual improve-

14 Ibid., 1909, p. 281.

15 Ibid., 1901, p. 546.

16 The charter members of the organization were: D. B. Nims, John E. Brown, Fred Hethershaw, D. B. Patterson, M. Mitchell, and N. J. Harris. The officers elected at this time were: John E. Brown, president, D. B. Nims, vice-president, and N. J. Harris, secretary-treasurer. Iowa State Department of Agriculture, Iowa Year Book of Agriculture, 1901, pp. 546-547.

17 Ibid., p. 547. 
ment and protection. To encourage among seed corn growers an honorable competition to produce for sale seed corn having the highest degree attainable of germination and of production. . . To encourage and advance the present high standard of excellence of varieties now grown in the state. . and to encourage the development of new varieties by holding corn shows, distributing literature and any other legitimate means of disseminating knowledge along the line of advanced corn culture. . To establish a school for training in score card work, in judging corn and giving certificates of proficiency to persons found competent. 18

With this avowed purpose these men worked to increase the membership of the Association and to improve the corn produced in the state. The membership included those persons "actually engaged in the growing of improved or purebred corn for seed purposes. . . and such other persons not to exceed in number one-third of the entire membership whose knowledge and interest in the objects of the Association may entitle them to membership."19 To a degree these men were successful in inducing the growers of the state to join them in their efforts to improve corn production. The six charter members in 1901 grew to eighteen by $1905,{ }^{20}$ which is a commendable growth considering the limitations placed on membership.

In an attempt to improve the strain of corn produced in Iowa, the members held semi-annual meetings at which such problems as the selection of seed and the cultivation of corn were discussed. Thus, much was done to instruct the farmer in bettering his corn. Some members felt, however, that the greatest work of the Association was in devising a score card by which corn could be judged. The card originated by this society is reputed to be the first in the country. According to the members it became the model for the score cards of the entire

18 Iowa Seed Corn Breeders' Association, Constitution and By-Laws, Article 2.

10 Ibid., Article 3.

20 Interview, Fred Hethershaw, former Secretary, Iowa Seed Corn Breeders' Association, April, 1932. 
United States. ${ }^{21}$ The score card used by the Association at this time follows:

$\begin{array}{lr}\quad \text { Characteristics } & \text { Point } \\ \text { Length of ear } & 12 \\ \text { Circumference of ear } & 8 \\ \text { Shape of ear and trueness to type } & 10 \\ \text { Ripeness or maturity } & 10 \\ \text { Color of grain and cob } & 5 \\ \text { How filled out at both ends } & 10 \\ \text { Number of rows } & 5 \\ \text { Length of grain } & 5 \\ \text { Perfection and uniformity of grain } & 5 \\ \text { Per cent of grain to cob, } 3 \text { ears } & 15 \\ \text { Weight of shelled corn, } 3 \text { ears } & 15\end{array}$

Characteristics

Length of ear

12

8

10

10

5

10

5

5

5

15

15

This card was described in the following way:

The above score card is not intended to be used in judging for sweepstakes but exhibits of the same variety. It does not require perfection but incites the exhibitor to emulation. It encourages distinctiveness of type among varieties. Its use is intended to be an encouragement to the study of the valuable characteristics of corn and not merely a way of dividing premium money. ${ }^{23}$

The Iowa Seed Corn Breeders' Association continued its work until 1905. With the development of the Corn Growers' Association under the leadership of Professor Holden at Ames, the members of the former organization decided to disband and to co-operate with the newer society. They felt that by working with the State College more could be accomplished. Since state funds were appropriated to the College, extensive research and experiments could be undertaken. ${ }^{24}$

The importance of the Iowa Seed Corn Breeders' Association is in the production of a score card and in the fact that it was the first movement toward the improvement of corn. It is responsible for stimulating an especial interest in the improvement of corn in Iowa.

Corn Belt Meat Producers' Association

The final and perhaps the best known of this group 21 Ibid.

22 Iowa Seed Corn Breeders' Association, Constitution and By-Laws, Article 9.

23 Ibid.

24 Interview, Fred Hethershaw, former Secretary, Iowa Seed Corn Breeders' Association, April, 1932. 
of societies is the Corn Belt Meat Producers' Association, which was organized to combat the railroad practices in issuing passes. In 1905, the railroads threatened to abrogate the return pass issued to stock shippers who accompanied their stock to market, and, since this pass was deemed essential by the shippers, they decided to unite to force the continuance of the practice then in vogue. From this situation came the Corn Belt Meat Producers' Association, ${ }^{25}$ organized that year with Asa Ames of Buckingham, president, and James Ryan of Fort Dodge, secretary.

According to the constitution adopted at that time, the membership of the state Association was composed of all shippers who were members of local or county associations. ${ }^{26}$ Like other farm organizations, the state unit of the Corn Belt Meat Producers' Association united the local or county associations. These latter groups were organized on the same basis as the state society. They allowed any shipper to become a member of their organization and agreed to cooperate with the state Association. ${ }^{27}$ These local groups were represented in the state organization by delegates who elected the officers and directors of the state society. The directors undertook the general management of the Association, and transacted all its business. ${ }^{28}$ In addition, they were to represent their district in the annual meeting.

Turning from the physical make-up of the Association, it is interesting to note some of its more important leaders. As stated above, Mr. Ryan was the first secretary of the society. He was more or less the "firebrand" type, whose unusual ideas kept him in the public eye. This was an advantage to the society for his publicity helped focus public attention on the organ-

25 Interview, H. A. Wallace, Editor, Iowa Homestead and Wallace's Farmer, August, 1931.

26 Corn Belt Meat Producers' Association, Annual Report, 1906 (Des Moines: Corn Belt Meat Producers' Association, 1907), p. 40.

27 Corn Belt Meat Producers' Association, Second Annual Report, 1907 (Des Moines: Corn Belt Meat Producers' Association, 1908), p. 42.

28 lbid., p. 41. 
ization. Thus, the Association became well-known and interest in it was stimulated so, in succeeding years, the officials could devote more time to their business and less to advertising the society. In 1906 he was succeeded in office by $\mathrm{H}$. C. Wallace, a very unassuming man. He worked quietly but accomplished much. Mr. Wallace served in this capacity until his death in 1924, when he was succeeded by his son, H. A. Wallace. ${ }^{29}$

A year after Mr. H. C. Wallace's election as secretary of the Corn Belt Meat Producers' Association, Clifford Thorne became its attorney. ${ }^{30} \mathrm{He}$ was induced by H. C. Wallace to represent the Corn Belt Meat Producers' Association in its dispute with the railroads concerning rates. At first $\mathrm{Mr}$. Thorne was slow to assimilate the statistical trend that his new work was to take since his previous training had all been in the direction of the theory of law, but, with growing familiarity, he became very efficient. It was through his efforts that the Association was able to accomplish much of its work in regard to rates. ${ }^{31}$ As a result of his activities with the Association, he became the most noted railroad attorney of his time.

In $1908 \mathrm{Mr}$. A. Sykes of Des Moines became president of the organization and continued in that office until 1926. He was very efficient and his efficiency, combined with unusual ability and a pleasing personality, proved very valuable to the society.

These three men, Mr. Sykes, Mr. Wallace, and Mr.

29 Interview, H. A. Wallace, Editor, Iowa Homestead and Wallace's Farmer, August, 1931.

${ }^{30} \mathrm{Mr}$. H. A. Wallace described Thorne as follows: Mr. Thorne was a very brilliant man with a great deal of dynamic power although he was very irritable. He was the son of a Methodist minister and, as a youth, he moved frequently as is customary with the families of preachers. In moving, Clifford often skipped a grade in school with the result that he had a Doctor's Degree from Yale at the age of 22 . In 1923 Thorne ran against Brookhart in the primaries for U.S. Senator, but was defeated. This was a great blow to him, but he found solace in a trip abroad. While on his world tour, he caught cold in London and died, leaving a widow and a small daughter. Interview, H. A. Wallace, August, 1931.

31 Interview, H. A. Wallace, Editor, Iowa Homestead and Wallace's Farmer, August, 1931. 
Thorne, were very influential in the organization. ${ }^{32}$ It was felt by some of the members that this trio was responsible for most of the Association's achievement. ${ }^{33}$

The Corn Belt Meat Producers' Association directed its efforts chiefly toward obtaining favorable railroad rates for agriculture. The Association represented the farmers before the Interstate Commerce Commission to prevent a general advance in rates. It obtained a decision and order from the Iowa Railroad Commission preventing the railroads from increasing the minimum carload shipping weight on livestock within the state. It took the leading part in defending the farmers before the Interstate Commerce Commission. It was estimated by the Association that the proposed rate advance would have cost the Iowa feeders one-half million dollars. ${ }^{34}$

A summary of other outstanding achievements of this Association was given by $\mathrm{Mr}$. Sykes in an address at its 1911 annual meeting. ${ }^{35}$ At this time, he declared that the organization had secured the stockmen's return pass for the shipper and had obtained improved stock-train schedules. He felt that the poorest service had been rendered by the C. B. \& Q., but that, due to pressure exerted by the Association, the service was rapidly improved. He further claimed that, as a result of the activities of the society, full value was then being paid for stock crippled in transit whereas formerly only 50 per cent of their value had been allowed. According to its president, the Association had succeeded in getting an 18 per cent reduction in rates on livestock within Iowa, which annually saved $\$ 50,000$ for the farmers, and had obtained a reduction of 25 to 50 per cent in the rate of feeding sheep. Mr. Sykes claimed also that the Association was responsible for the re-

$32 \mathrm{Mr}$. Sykes was given $\$ 2,000$ per year and $\mathrm{Mr}$. Thorne was retained for $\$ 1,000$ annually, but no other salaries were paid by the society.

33 Interview, H. A. Wallace, Editor, Iowa Homestead and Wallace's Farmer, August, 1931.

34 Iowa State Department of Agriculture, Iowa Year Book of Agriculture, 1911 (Des Moines: State Printer, 1912), pp. 133-134.

35 Ibid. 
grouping of Iowa-Chicago rates on cattle and sheep, so that the rate for sheep in double deck cars was the same as for cattle. It had secured a change in water at the Chicago Stockyards from the Bubbly Creek to lake water which saved a 25 per cent shrinkage in the animals; and finally it had been responsible for the establishment by legislative act of a Commerce Counsel who was to represent the people before the Railroad Commission or the Interstate Commerce Commission in all questions regarding rate disputes.

In addition to its efforts to obtain just treatment for the farmer in shipping, the Association strenuously opposed the activities of the Food Commission during World War I and in the post-war period. The opposition stemmed from the Association's interpretation of the Food Commission's attitude toward meat prices. The members of the Commission, claimed the Association, thought of all livestock in terms of calories and demanded that it be sold cheaply to furnish food for the needy. Without consideration of the producer, so the Association felt, the market price of livestock was forced down so that meat would be cheaper. As a result, the feeders lost staggering sums in the sale of their stock. The Association estimated losses on cattle from $\$ 50.00$ per head on baby beeves to $\$ 60.00$ per head on heavy beeves and, on hogs, about $\$ 5.00$ per hundred pounds. ${ }^{30}$

Another phase of this organization's work was an attempt at cooperative marketing. In 1907 the Association established a Cooperative Commission Board in Chicago. However, it was opposed by other livestock commission firms who organized a boycott against it. This action forced the Board to cease functioning within a year. ${ }^{37}$

The Association accomplished its best work between 1908 and 1920. Although it continued operation until the late 1920's, its importance dwindled. The last sig-

${ }^{36}$ Interview, Henry A. Wallace, Editor, Iowa Homestead and Wallace's Farmer, August, 1931.

87 Ibid. 
nificant action of this organization was to represent the farmers on a rate case in Kansas City in $1926 .{ }^{38}$

With the organization of the Farm Bureau in 1918 and the Iowa Cooperative Shippers' Association in 1921, the Corn Belt Meat Producers' Association gradually faded from the agricultural scene in Iowa. The members of the older Association were active in organizing the younger ones. At a Marshalltown meeting of the Farm Bureau the Corn Belt Meat Producers' Association was well represented. Mr. H. C. Wallace reported that the spirit of the meeting was reminiscent of the conventions of the Meat Producers' Association in its prime and he was very hopeful of the outcome. ${ }^{30}$ The Corn Belt Meat Producers' Association felt that, since the Cooperative Shippers' Association would apparently duplicate its efforts to establish cooperatives and the Farm Bureau, its other work, its continuance would merely divide the farm membership. Consequently, it ceased its operation as an independent organization and its members became active in the new societies.

Three of these four farm organizations were primarily educational. The Corn Belt Meat Producers' Association was the only one which had economic activity as its chief concern. It is interesting to note that three of these organizations had the betterment of livestock and the improvement of the status of the stock breeder as their objectives. Improvement of grain and the grain farmers' status apparently was considered of secondary importance in the earlier period of Iowa's history.

All of these associations played an important part in Iowa agricultural history and through them the Iowa farmers received much information regarding methods of feeding and breeding of livestock; they also encouraged and aided the farmers in the development of better strains of corn. Undoubtedly the efforts of these organizations influenced the agricultural development of Iowa and aided her in becoming renowned as a hog and corn producing state.

38 Ibid.

89 Ibid. 
Copyright of Annals of Iowa is the property of State of Iowa, by \& through the State Historical Society of Iowa and its content may not be copied or emailed to multiple sites or posted to a listserv without the copyright holder's express written permission. However, users may print, download, or email articles for individual use. 